\title{
Politics and Higher Military Education in Bosnia and Herzegovina: A Missed Opportunity
}

\author{
Heinz Vetschera ${ }^{*}$
}

\section{Introduction}

Developing higher military education (HME) is embedded in the overall development of modern armed forces. This development normally reflects adaptation to changes in the external strategic environment, changes in military technology and doctrine, and changes in the societal environment of the armed forces.

While this is true for armed forces with an unbroken tradition, the pattern differs when a given military's development had been interrupted by historical events. This article will focus on the situation in Bosnia-Herzegovina $(\mathrm{BiH})$, which constitutes a unique case in itself. The particular political situation in Bosnia-Herzegovina after the break-up of Yugoslavia, the ensuing war of 1992-95 and the General Framework Agreement on Peace ("Dayton Agreement") of December 1995 had led to a rather de-centralized state structure, with two largely autonomous political "Entities" that each kept the armed forces they had established during the war, leading to the de facto military division of $\mathrm{BiH}$. Thus, when the West initiated a defense reform process in $\mathrm{BiH}$ in 2002, it aimed first at establishing state-level control over these armed forces (2003), and then at merging them into one single military force for the nation (2005), with other issues mostly put on the back burner. ${ }^{1}$

This was also the case with regard to military education. While a coherent system for the training and education of the now joint state-level armed forces of BiH would have been a key element for completing defense reform, it has not yet been established. There have been serious attempts, but up to this point they have failed. Thus, this article will:

- Briefly outline the political and military situation in BiH, including the lack of a coherent system of military education

- Present early initiatives within the context of defense reform as well as parallel to it

\footnotetext{
Dr. Heinz Vetschera, BG (res) is a former researcher and lecturer at the Austrian National Defense Academy (ANDA) and adjunct professor at Vienna University. He is also an associate faculty member of the Baltic Defense College. During his various assignments in Bosnia-Herzegovina he participated in the Defense Reform Commission (2003) and served from 2007 until 2012 as Academic Lecturer at the Peace Support Operations Training Center (PSOTC). This article is based upon the author's experiences during his participation in the reform process from 2007 until 2012, and expresses his personal views. It does not reflect the positions or policies of the Austrian, BiH or United Kingdom Ministries of Defense, the PSOTC, the Austrian National Defense Academy, the Partnership for Peace Consortium, or Connections.

1 The only exception had been the establishment of democratic, parliamentary control over the armed forces.
} 
- Describe the initiatives undertaken in establishing higher military education as well as the resistance they met

- Assess the process with respect to its impact, including the causes of its failure.

\section{The Situation in Bosnia-Herzegovina}

The break-up of the former Socialist Federal Republic of Yugoslavia (SFRY) also meant the break-up of the former Yugoslav People's Army (Jugoslovenska Narodna Armija, or JNA $)^{2}$ and the establishment of national armed forces by the successor states. While Serbia inherited the mostly intact military system of the JNA (including its high-quality military academy), the seceding states ${ }^{3}$ in most cases achieved their statehood through wars of independence, ${ }^{4}$ with forces mostly derived from the JNA's territorial defense system, but at least in a coherent structure.

In Bosnia-Herzegovina, the war following the declaration of independence in April 1992 was both a war of secession from Yugoslavia but also between the three major ethnic groups in BiH (Bosniaks, or Bosnian Muslims; Serbs; and Croats),with ongoing intervention by neighboring Serbia and Croatia. ${ }^{5}$

Fighting between Bosniaks and Croats ended when the United States brokered a "Federation" between them in 1994. After Western intervention in 1995, the Serbs also accepted a cease-fire, which then led all parties involved to agree on the "General Framework Agreement on Peace" (the "Dayton Agreement," or DPA) in late 1995. The DPA established a rather decentralized state structure, ${ }^{6}$ with two highly autonomous political entities, the (Muslim-Croat) Federation of Bosnia-Herzegovina and the (Serbdominated) "Republika Srpska." Furthermore, the DPA allowed the two entities to maintain their wartime forces. Thus, for ten years there were two separate armies within one state, implicitly pitched against each other, but also following different models of

2 While the SFRY had not been a member of the Warsaw Pact, its military was with some exceptions based on their partisan tradition and Eastern models, mostly embodied in its doctrines and structures.

3 Like Slovenia and Croatia and the Former Yugoslav Republic of Macedonia (FYROM), but also Bosnia-Herzegovina under even more specific conditions (see below).

4 Except for the independence of FYROM (1991) and Montenegro (2006).

5 The "ethnicity" of these three groups is based less on linguistic differences than on religious criteria. Bosniaks (approx. 45 percent of the population) are Muslims; Serbs (approx. 33 percent) are Orthodox Christians; Croats (approx. 17 percent) are Roman Catholic. All data are based on the pre-war census of 1991; reliable figures since independence are difficult to come by, as no further census has been conducted since then.

6 The constitution of Bosnia-Herzegovina has been enshrined within the Peace Treaty as one of its Annexes (Annex 4). BiH is thus a country with an externally imposed constitution.

7 The Federation itself was again sub-divided into ten cantons with a high degree of autonomy, in such areas as education, police, justice, etc. 
doctrines and education. ${ }^{8}$ Only in 2002 was a reform process initiated that led in stages to the creation of unified armed forces in 2006.

\section{The Lack of a Coherent System of Military Education and its Impact on the Military Situation}

During the armed conflict that lasted from 1992 to 1995 , the various armies had almost no training and education systems of their own. ${ }^{9}$ This pattern persisted after the peace accords within the separate armies of the Federation of Bosnia-Herzegovina and Republika Srpska. Training and education were frequently "outsourced" to politically affiliated states, which in turn enabled these states to exert some ideological or political influence over the respective forces within $\mathrm{BiH} .{ }^{10}$

The armed forces of Republika Srpska ${ }^{11}$ relied extensively on the then Federal Republic of Yugoslavia (FRY) — which consisted of the former Yugoslav Republics of Serbia and Montenegro-but some officers were also trained in Greece. ${ }^{12}$ In substance, training of RS officers followed more or less along the traditional models embodied in the former JNA.

In the Federation, training was mostly conducted within $\mathrm{BiH}$ under the U.S.-backed "Train and Equip" program, which aimed at creating a Western, NATO-compatible system of training and education. On the institutional side, a Training and Doctrine Command (TRADOC) was established with subordinate units. ${ }^{13}$ In substance, training and education followed a Western orientation, and was based on translated U.S. documents. ${ }^{14}$ There was, however, also some "outsourced" training, with Bosniaks sent mostly to Turkey and other Muslim countries like Pakistan, Malaysia, and the United Arab Emirates. Some Croats were sent to Croatia. In addition, officers from the Federation were sent to various NATO and PfP countries. ${ }^{15}$

8 The situation was once described as follows: "the only conceivable enemy for a Bosnian soldier is another Bosnian soldier."

9 For a while, each ethnic group (Bosniaks, Croats, and Serbs) had their own armed forces. The Croat and Bosniak Armies were merged only with the U.S.-backed founding the Federation in 1994.

10 The BiH General Staff's 2011 Concept on the Development of Officers (Koncept profesionalnog razvoja časnika OS BiH) indicates that within the current personnel, officers have graduated from more than 630 various courses in as many as 55 nations.

11 Vojska Republike Srpske/VRS (Army of the Serbian Republic [the Serbian Entity within $\mathrm{BiH}])$.

12 All data from BG (ret.) Alain Lamballe, Senior Adviser to the Head of [OSCE] Mission in Bosnia and Herzegovina for Military Academic Institutions, Training of Officers of the Armed Forces in Bosnia and Herzegovina and of Civilians on Defence and Security Issues (Sarajevo, 2002), 9.

13 The Center for Professional Development (CPD), the Combat Simulation Center, and various Recruit Training Centers.

14 Lamballe, Training of Officers of the Armed Forces in Bosnia and Herzegovina, 3-4.

15 Ibid., 8. 
An assessment at that time came to the conclusion that "there is no link of any kind between the entity armies about training. The various training establishments which exist in the Federation and in the RS never exchange their experience. They ignore each other." 16

\section{Defense Reform and Military Education}

To overcome this division, in 2002 the Western actors in $\mathrm{BiH}$ initiated the process of defense reform, which officially started in 2003. It led, in its first stage, to establishing state-level command and control in $2004,{ }^{17}$ and in its second stage to establishing a single state-controlled Army of Bosnia and Herzegovina in 2006. ${ }^{18}$

\section{Efforts Within the Defense Reform Commission}

Matters of military education were addressed within the second phase of the reform process (2004-05). Within Working Group 2, several working presentations ${ }^{19}$ and working papers ${ }^{20}$ were elaborated, practically anticipating the ideas put forward by the Ministry of Defense (MoD)'s Officers' Training Commission from 2008 onwards. ${ }^{21}$ However, these proposals did not find their way into the report of the Defense Reform Commission (DRC).

It was even assessed that defense reform had had a negative impact, that "one of the downsides of defense reform has been the suspension of many training programs, including that for new officers and soldiers...." 22 The situation remained problematic, as officers in the newly joint armed forces essentially shared no common educational background, which impeded joint operations and staff work. ${ }^{23}$ The lack of joint training and

16 Ibid., 7.

17 At that stage, the Federation and Republika Srpska maintained their own armed forces, which were, however, brought under state command and control $\left(\mathrm{C}^{2}\right)$ via state legislation, a statelevel ministry of defense, and a state-level general staff and operational command. See the report of the Defense Reform Commission, The Way to Partnership for Peace (Sarajevo, 2003). The author participated in the Defense Reform Commission during its first phase.

Thereby completely abolishing the entities' armed forces; see the Final Report by the Defense Reform Commission, A Single Army for the $21^{\text {st }}$ Century (Sarajevo, 2005).

19 MG (ret.) John Drewienkiewicz, then Director of the OSCE Mission's Department for Security Cooperation; Vice-Chair of the DRC and also chairman of WG 2, "Requirements for Training and Education," PowerPoint presentation (no date). The author has received a printed copy from the OSCE Mission's Department for Security Cooperation.

20 DRC Team 2, "Future Individual Officer Education and Training in the AF BiH - A Concept Paper," draft paper (21 September 2005).

21 See below. This is no coincidence, as Drewienkiewicz also wrote the concept paper for that workshop.

${ }^{22}$ Ken Lindsay, "Memorandum on Military Education and Doctrine in the AF BiH," NATO Transition Management Group (10 May 2007).

23 Except for the rather decreasing number of those still coherently trained and educated in the pre-war JNA. 
education prevented the development of a truly joint esprit de corps. The effects of defense reform were thus undercut by the lack of joint training and education within the armed forces of $\mathrm{BiH}$. Such a common foundation would have been a crucial element in the effort to solidify reform, as coherent armed forces appear inconceivable without coherent education.

\section{Initiatives Parallel to Defense Reform}

Initiatives for joint military education had already started at about the same time that defense reform efforts took off, but in rather isolated steps. As early as 2001, the U.K. Joint Services Command and Staff College undertook a "Study into the Feasibility of Establishing a Joint Leadership College for the Armed Forces in Bosnia and Herzegovina." 24 It suggested undertaking peace support training and education as the best course of action, which was intended to close some gaps with respect to peace support operations (PSO) training but also to implicitly allow for some joint training of the then still separate forces of the Federation of Bosnia-Herzegovina and Republika Srpska.

As a result, in 2003 the Peace Support Operations Training Center (PSOTC) was established. Its first purpose was to provide joint training in peace support operations for $\mathrm{BiH}$ soldiers participating in such operations. ${ }^{25}$ Second, however, it was intended to provide for joint training and education in general, anticipating the envisaged merger of the separate forces. ${ }^{26}$ It was established as an international institution sui generis by a group of like-minded states, and was to be governed by a management board representing these states. Its staff contained both personnel seconded by these states, and from the BiH armed forces. ${ }^{27}$ The Commandant and the Director of Studies (or DOS, who was de facto the Commandant's deputy) were, at the outset, international staff. The center was intended to maintain its international character for the following ten years (2003-13). By

24 Joint Services Command and Staff College, "Study into the Feasibility of Establishing a Joint Leadership College for the Armed Forces in Bosnia and Herzegovina," BTSR/01/01, 29 April 2002.

25 Paragraph 1 of the PSOTC's Mission Statement reads: “To deliver internationally approved education and training to selected junior officers of the Armed Forces of Bosnia and Herzegovina and invited international students, who will lead and train others in multinational peace support and humanitarian operations."

26 Paragraph 2 of the PSOTC's Mission Statement reads: "To develop new courses and seminars that are of the benefit for the Armed Forces of Bosnia and Herzegovina or other parts of the BiH security sector."

27 At the beginning from the separate armed forces of the two entities (Federation and Republika Srpska), then of the joined armed forces of $\mathrm{BiH}$. 
then, the center was to have been developed into a staff college and handed over to the Armed Forces of $\mathrm{BiH}^{28}$

\section{Elements of Military Education after Defense Reform}

With the merger of the armed forces into a single Army of $\mathrm{BiH}$, the former Federation Army's TRADOC became a state-level institution. It developed various courses, including a four-month staff course, with all training conducted in Bosnian. On the other side, since its inception the PSOTC had developed a Junior Peace Support Operations Staff Course, with a mix of staff officers' training and specialized training for peace support operations. Training was conducted exclusively in English.

Further courses were developed outside the military, such as a course for military attachés offered by the Geneva Centre for Security Policy (GCSP), or seminars on security policy organized by the OSCE Mission in Bosnia and Herzegovina. Also, several universities in $\mathrm{BiH}$ had added security policy-oriented subjects to their curricula. ${ }^{29}$ All these developments had, however, taken place entirely independently of each other. While they could be seen as a kind of emerging pattern of higher military education, they could not be assessed as a system.

\section{The Window of Opportunity Opens}

Practically parallel to the implementation of the defense reform process, elections were held in October 2006, and a new government was appointed in early 2007. The new Minister of Defense was Selmo Cikotić, a former professional military officer who was embarking on an academic career. His proclaimed objectives were pursuing BiH's accession to NATO membership, and establishing a system of military training and education. He initiated a process for developing a coherent system of military education and expanding the PSOTC into a defense college with full academic accreditation.

For this, he arranged for an expert from the Austrian National Defense Academy (ANDA) - the author of this article - to join the PSOTC in the position of academic lecturer and to be available for the development of a system of higher military education. The expert offered an optimal combination of professional and academic experience as well as decades of in-country work, including participation in the DRC. After a short period of negotiations, I joined the PSOTC as Academic Lecturer in late 2007.

After some preparations in close cooperation with the NATO Advisory Team attached to the $\mathrm{BiH} \mathrm{MoD}$, the Minister adopted a decision on 24 March 2008 installing a working group "for education and training of officers in the Armed Forces of BiH,"

28 As late as March 2006, the then-DOS of the PSOTC is on the record as stating that "in the long run [the PSOTC] would be turned into the $\mathrm{AF} \mathrm{BiH}$ Command and Staff College and given to the $\mathrm{BiH}$ authorities as a gift." See the minutes of the "Academic Partnership between PSOTC and Sarajevo University," Faculty for Political Science, Meeting no. 02-2006 (8 March 2006). The future function appears to have been out of question at that stage, which changed only subsequently.

29 As, for example, the universities in Sarajevo, Banja Luka, and Bihać. 
called the Commission on Military Training and Education. ${ }^{30}$ The Commission had a broad range of participants, and was tasked with preparing a single education and training concept for the $\mathrm{AF} \mathrm{BiH}^{31}$

As a first step, at a workshop in early April 2008 the group focused on Basic Officers' Training (BOT). ${ }^{32}$ The results of the working group's deliberations were submitted to the Minister of Defense, and subsequently transformed into policy decisions. First officer's cadets were to be trained from late 2009 onwards.

In July 2008, the Minister of Defense asked me to write a concept paper on higher military education, covering the requirements for courses, educational institutions, and how to integrate existing courses and institutions into one coherent system. The paper was submitted to the Minister in the late fall of 2008. It analyzed the requirements and options for higher military education in Bosnia and Herzegovina, and suggested a coherent course structure, from a staff officers' course to a "Strategic Leadership Course." It suggested that higher military education should be compatible with academic education in the civilian sector. A Defense Academy of Bosnia and Herzegovina should provide the institutional framework for most courses (except for the junior staff course), compatible with similar institutions in other countries. The establishment of both courses and institutions could be based upon existing "precursors," such as the PSOTC.

\section{A Cold Wind Blows through the Open Window}

While both the Minister's original intentions and the concept paper would have given a prominent role to the PSOTC in future higher military education, the idea was not supported by the new leadership of the PSOTC. The first PSOTC commandant had been explicitly supportive of the idea of developing the PSOTC into a defense college with an academic character - a concept that had been in place as late as March 2006. ${ }^{33}$ However, his successor, who took over the center in 2007, had a more traditional

30 No. 10-33-2-1328-1/08.

31 The participants included the Expert on Higher Education from the Council of Europe's Mission in Sarajevo, who expressed the hope that academically qualified professional military education as a state-level undertaking would simultaneously also lead to overcoming the political fragmentation of higher education in general in $\mathrm{BiH}$.

32

Deliberations were based on a concept paper provided by MG (ret.) Drewienkiewicz: "A Concept paper on the shaping of Higher Military Education submitted to the working group established by Decision of the Bosnia and Herzegovina MoD," no. 10-33-2-1328-4/08 (24 March 2008).

33 The first PSOTC Commandant was a Danish Brigadier General who served from 2003 to 2006. During his tenure, the future role of the PSOTC as the AF BiH Command and Staff College was unquestioned. See the above quotation from the minutes of the "Academic Partnership between PSOTC and Sarajevo University" from March 2006 that "[the PSOTC] would be turned into the AF BiH Command and Staff College. As an example of his academic ambitions for the center, he had introduced into the staff course's curriculum a research paper to be written by the students, known as the "Commandant's Paper." It was then abolished by his successor as "too academic," and re-introduced only under the following PSOTC Commandant, who was from $\mathrm{BiH}$. 
approach. First, he emphasized the military "training" aspect, in particular a narrow focus on peace support operations. While he successfully worked to establish the PSOTC as a regional training center ${ }^{34}$ at the same time he gave less attention to the political objectives in consolidating defense reform in $\mathrm{BiH}$ by establishing higher military education. ${ }^{35}$ Second, in the same vein he also challenged the value of academic qualifications in military education. ${ }^{36}$ Third, he had difficulties in detaching himself from his national background. ${ }^{37}$ Finally, he developed a problematic relationship with the host country, ${ }^{38}$ in particular with the $\mathrm{BiH}$ armed forces and their emerging educational system, which he viewed as competitors rather than future beneficiaries of the PSOTC's work. ${ }^{39}$ This attitude led, in reciprocity, to increasing animosity on the $\mathrm{BiH}$ side, in particular on the part of TRADOC not only against the Commandant as a person but also towards the PSOTC as an institution. Finally, when I had completed my concept paper for the Minister of Defense, the Commandant confronted the Minister

34 The PSOTC achieved accreditation as a "PfP Training and Education Center" in 2008, and was later recognized as one of three regional PfP Centers of Excellence in South East Europe.

35 When the idea of transforming the PSOTC into the country's future defense college was discussed, the Commandant brushed the notion off with the remarks that the country would be "too small for such a requirement" and that "they all should go to Belgrade - the Military Academy there is big enough for all," completely ignoring the political background of the wars of secession, which were in significant part caused by the centralist tendencies in Belgrade.

36 As early as June 2008 I achieved a consensus among all eight public universities in $\mathrm{BiH}$ that they would accept the curriculum of the PSOTC's staff course as part of regular management studies. Given the political and ethnic fragmentation of the $\mathrm{BiH}$ educational system (five universities are Bosniak/Muslim, two are Serbian/Orthodox, and one is Croat/Catholic), this would have been a political breakthrough to pave the way for academically qualified professional military education accepted by all three ethnic groups. This proposal was, however, shot down by the Commandant, who quoted his national chief of the general staff's statement that "we do not need academics but warriors."

37 He frequently used his national experiences as the only point of reference, as when he denied the necessity for legal services in the armed forces "as we do not have them, either"- a statement strongly contradicted by a U.S. staff member, who referred to their JAG system. In this attitude the Commandant was followed and even surpassed by his Director of Studies from the U.K., who persistently remained within his national bubble.

38 For example, when he received an invitation to participate in a seminar organized by the J-2 branch of the Armed Forces of $\mathrm{BiH}$, he refused participation with the argument, "We do not talk with them."

39 For example, he demanded that the TRADOC's CPD should terminate their staff course, as that would be in competition with the course at the PSOTC. While this was true in substance, it also revealed a certain contradiction in his attitude. On the one hand, he refused a distinct national role for the PSOTC (namely in higher military education), but on the other hand he saw national efforts in this field by the CPD as competing with his own institution. There would have been cooperative solutions that could have addressed this seeming competition, such as having a two-stage approach as indicated in my concept paper. First, the "national" staff course at the CPD in the national languages for all qualified officers, and then a selective international staff course in English at the PSOTC. 
directly, and could only be placated when the Minister assured him that the paper was not directed against the PSOTC, and offered him a role in developing a Command and General Staff Course (CGSC) for BiH.

\section{The Workshops on Higher Military Education}

Based upon the concept paper and parallel studies conducted within the MoD, the NATO Advisory Team organized another workshop in February 2009. It was intended to build on the results of the former workshop on BOT, and to help develop a system of higher military education. The seminar program was based on a "strawman" paper by MG John Drewienkiewicz, and on my concept paper. ${ }^{40}$ It followed a comprehensive approach, ranging from the issue of overall personnel development in the Armed Forces of $\mathrm{BiH}$ to the envisaged course structure, the institutional requirements, and the future role of the PSOTC. The seminar conclusions mostly followed the "strawman" paper. ${ }^{41}$ They strongly suggested establishing a $\mathrm{BiH}$ defense college for all higher military education, while TRADOC's Center for Professional Development would run courses below that level.

\section{The Following Steps}

As a result of the seminar, the Ministry of Defense invited the PSOTC to develop the GCSC, which should end with a Masters' degree. The MoD and the PSOTC in May 2009 agreed to establish a project group and a steering group for this purpose. Furthermore, the PSOTC would draft a paper preparing a decision by the BiH collective tri-ethnic presidency to establish the defense college. It would also inform the PSOTC's partner states about the development. Subsequently, the PSOTC established a distinct planning element for the envisaged Command and General Staff Course, including its academic accreditation, and to manage the transition into the $\mathrm{BiH}$ defense college. In addition, the PSOTC's then-nascent participation in the PME Reference Curriculum Development Team of the PfP Consortium's Education Development Working Group (EDWG) would have provided an opportunity for $\mathrm{BiH}$ to gain knowledge that would have been useful for its own curriculum development.

Finally, at the end of 2009, the international (and still skeptical) PSOTC Commandant was replaced by a $\mathrm{BiH}$ officer with optimal qualifications for this position. He had a distinguished military career, experience both abroad and with the PSOTC (where he had been Chief of Staff), and academic qualifications, with a Ph.D. in political science

40 See MG (ret.) John Drewienkiewicz, "Strawman Paper on Professional Officer Development and Training in the Armed Forces of Bosnia and Herzegovina," paper written for the NATO HQ Sarajevo (4 Feb 2009).

41 "Polazni dokument o profesionalnom razvoju oficira i obuci u Oružanim snagama Bosne i Hercegovine; Dokument napisan za Ministarstvo odbrane BiH, 3 Mart 2009" ("Introductory Document on the Professional Development of Officers and Training in the Armed Forces of Bosnia and Herzegovina. A Document written for the Ministry of Defense of BiH, 3 March 2009"). 
and lecturing at Sarajevo University. Thus, in 2010 there were finally optimal conditions for establishing higher military education in Bosnia and Herzegovina, based on the previous work of the commissions and the various but rather coherent concept papers.

\section{The Window Closes}

The series of workshops was continued in May 2010, but without the participation of the NATO Advisory Team or any other external experts. ${ }^{42}$ The General Staff presented a coherent paper addressing the overall issues of the officers' professional development, including overall professional development and education, following mostly along the lines of previous workshops. ${ }^{43}$ During the meeting, however, a growing polarization became visible, first between "old thinking" vs. "new thinking," but also with respect to the incipient election campaign. ${ }^{44}$ Nevertheless, the workshop elaborated an outwardlooking, well-structured educational system with a clear commitment to some education in English and academic qualifications in higher military education.

Little of this, however, was reflected in the next version of the paper. ${ }^{45}$ It lacked any reference to separate institutions of HME, and it favored TRADOC and its subordinate units. ${ }^{46}$ The subsequent version of March 2011 went even further, focusing exclusively on TRADOC, with only a rather vague reference to academic qualification. ${ }^{47}$

The reasons for this substantive shift can be traced to political developments. In May 2010, the campaign for the national elections (to be held in October 2010) had started. The Serbian side opposed any further development of state-level institutions ${ }^{48}$ and thus the idea of establishing new institutions for military education was no longer accept-

42 I participated in these workshops in my institutional role as the PSOTC's Academic Lecturer rather than in my expert function.

43 Bosnia and Herzegovina, Ministry of Defense, AF BiH Joint Staff, "Concept of AF BiH Professional Development" (draft),May 2010.

44 This polarization emerged, for example, with respect to the question of academic qualifications for HME, or the question of how much of the curriculum should be offered in English.

45 Bosnia and Herzegovina, Ministry of Defense, AF BiH Joint Staff "Koncept profesionalnog razvoja oficira OS BiH (nacrt)/ Concept of AF BiH Professional Development" (draft), May 2010. While this second version is also dated "May 2010," it is distinctly different from the document cited two notes earlier, and was distributed only in June.

46 "Command and General Staff School" was the term used in the paper. This compromise might have been the result of the Serbian side's refusal to accept terms like "Defense Academy," Defense College," "Staff College," or the like.

47 Bosnia and Herzegovina, Ministry of Defense, AF BiH Joint Staff, "Koncept profesionalnog razvoja časnika OS BiH (nacrt)/Concept of AF BiH Professional Development" (draft), March 2011. This version is written in the Croatian language ("časnik" instead of "oficir"). For the possible reasons for this, see below.

48 At a later stage, the provincial leadership of Republika Srpska went even further and demanded to abolish the armed forces completely. 
able. ${ }^{49}$ Second, there was also allegedly some resistance from the Croatian side, due to latent tensions between the Minister of Defense and the Croat faction in the Ministry. ${ }^{50}$ Other rumors indicated personal animosities as well as institutional jealousy against the still internationally-run PSOTC as possible reasons for resistance by the General Staff. While such rumors have to be treated with a certain caution, their mere existence is an indicator that the issues were not always addressed with the necessary reason and substance, but that they also met with a good deal of political bickering.

Finally, in 2011 it became clear that TRADOC's Center for Professional Development would become the leading institution. All career courses would be held at the CPD, while the PSOTC would be limited to the realm of peace support operations. It might, however, contribute specialized modules to career courses at the CPD.

\section{Outlook and Conclusions}

The development of higher military education in $\mathrm{BiH}$ appears to have been stopped in its tracks. Since the last workshop, no visible progress has been made. Also, when a new government was formed in late 2011, the new Minister of Defense showed evidently less enthusiasm for the establishment of a system of higher military education. With the transition to national ownership at the end of 2012, the PSOTC will be subordinated to TRADOC, with no leading role in military education. While there are thus some elements of PME discernible, there is, however, no development of HME visible within other institutions. The prospect of developing a functional, independent system of higher military education in $\mathrm{BiH}$ now looks rather remote.

Military education is a prerequisite for functioning armed forces, both from a purely technical perspective but also from a political perspective. This is even more true in the case of $\mathrm{BiH}$, where state-level armed forces had to be established in order to overcome the military-political division of the country. A coherent system of military education would have been a major cornerstone for a "Single Force for the Twenty-first Century. ${ }^{, 51}$ It appears surprising that the field of training and education, while addressed with rather concrete proposals in the DRC, did not find its way into the final report.

In contrast, the U.K. initiative in 2001, followed by the founding of the Peace Support Operations Training Center in 2003, was a far-reaching concrete project, establishing joint training even before the merger of the two entities' separate armed forces. These efforts, however, led to the development of parallel structures, with TRADOC developing its own training program, and to increasing competition between the two institutions.

49 Another possible reason was the fact that an academically qualified military (and thus statelevel) educational institution would have contradicted the (ethnically defined) entities' constitutional prerogatives in education, which were jealously guarded by both Serbs and Croats.

50 The use of the Croatian language in that latest version of the paper is seen as an indicator for this allegation.

51 Thus the title of the final report of the DRC in 2005. 
This could have changed with the initiative undertaken in 2007 by the newly appointed Minister of Defense, which opened a window of opportunity for establishing higher military education in $\mathrm{BiH}$, particularly since several circumstances appeared favorable at the time. ${ }^{52}$ The PSOTC as an international institution would have offered the chance to develop HME outside domestic political quarrels and the structure of such education before transfer to national ownership in 2013, making the process practically irreversible.

It did not materialize for several reasons. The first cause was the continuing political resistance within $\mathrm{BiH}$, in particular from the Serbian side. ${ }^{53}$ The second reason was the struggle of "traditionalists" versus "modernists," represented both on the international ${ }^{54}$ and on the BiH side. ${ }^{55}$ The third cause was the parallelism (and perceived competition) between the PSOTC and TRADOC's CPD. This issue could have been resolved in a cooperative manner, but this rapprochement did not materialize due to the personalities involved. ${ }^{56}$ Finally, some strong personalities involved were determined to push through their point of view.

The most decisive one was the PSOTC Commandant at that time who, in my opinion, resisted all efforts aimed at establishing full-fledged higher military education within the PSOTC. ${ }^{57} \mathrm{He}$ ignored the political requirements to support defense reform, refusing cooperation with TRADOC and other institutions of $\mathrm{BiH}$, and refusing to ac-

52 These circumstances include:

- The merger of the entities' armed forces and the establishing of coherent state-level armed forces

- The explicit political will of the new Minister of Defense

- The mere existence of the PSOTC, which was originally founded to be developed into a defense college

- The presence of foreign expertise ready to support such efforts (including the ANDA's Academic Lecturer assigned to the PSOTC, and the former chairman of the Defense Commission's pertinent working group)

- Support of the NATO Advisory Team in preparing and organizing workshops.

53

Which could, however, have been overcome during the "window of opportunity" period. There had been several indications from the side of the BiH Chief of General Staff (himself a Serb) that the development could go on, as long as "provocative" terminology (for example, "Defense College") was avoided. A similar pattern could be identified in the early stages of defense reform, when the Serbian side went along with concepts for state-level control, as long as terms like "Defense Ministry" were avoided.

54 With the PSOTC's Commandant at the time a "traditionalist," and the two foreign experts "modernists."

55 With the Minister of Defense a "modernist," and a larger group in the MoD and the General Staff "traditionalists."

56 When the PSOTC Commandant at the time in his attitude simply denied that BiH national institutions would achieve the quality required, the TRADOC Commandant was offended and retaliated by fighting the PSOTC as an institution.

57 In addition, his U.K. Director of Studies most probably influenced the U.K.'s position on the PSOTC Management Board, which became utterly negative since his taking office. 
cept that academic qualification would be an indispensable intellectual basis for HME. ${ }^{58}$ Finally, just when a national and more open-minded commandant was appointed to the PSOTC, the window started to close. ${ }^{59}$ The question got caught up in the election campaign, and after the elections in 2010 the issue of HME further lost momentum.

In conclusion, it appears an irony that practically all elements for establishing a coherent system of higher military education were in place in $\mathrm{BiH}$ when the window of opportunity opened in early 2008, except for the willingness of one individual. This failing is doubly ironic, since the PSOTC's international character was primarily meant to shield the issue from domestic politics in $\mathrm{BiH}$, allowing for the development of $\mathrm{HME}$ in a "neutral" environment. Instead, international representatives ultimately wound up blocking the development of this crucial field. ${ }^{60}$ The ultimate irony is that the establishment of the PSOTC as a precursor to a full-fledged military education institution was a U.K. initiative, ${ }^{61}$ yet since 2007 the U.K.'s representative on the PSOTC Management Board was one of the most vocal members opposing the development into a defense college. $^{62}$

Like in other instances in military history, it might have been individual personalities that turned a battle from possible success to failure. The prospects for repairing the damage are not foreseeable in the near future. There had been a reasonable chance to establish a system of higher military education for completing PME in $\mathrm{BiH}$, but the chance was missed, with all its political implications.

In conclusion, the crucial issue concerns the selection process for personnel sent to hold such positions. Solid military qualification is a necessary condition, but not a sufficient one. In selecting candidates for such sensitive international posts, states should also include criteria like cultural awareness, understanding of the political implications of various courses of action, a modern understanding of education, and open-mindedness in order to avoid similar failures in the future.

58 In addition to the implications a successful development would have had on the development of the civilian sector of higher education more generally.

59 The new appointment in itself was possibly a factor for the Croats' resistance, which inter alia might have brought the momentum to a halt.

60 Namely, the Danish Commandant and his British Director of Studies.

61 Namely based on the report of the U.K. Services Command and Staff College in 2001.

62 According to information received from a participant at the pertinent sessions, the U.K. representative repeatedly threatened to stop any financial contribution by his country if the course of development went in the direction of establishing a national defense college for $\mathrm{BiH}$. One can reasonably assume that this change of mind was, inter alia, determined by reports back to the U.K. Ministry of Defense by the U.K. officer serving at that time as Director of Studies at the PSOTC. 


\section{Bibliography}

A Single Army for the 21st Century. Sarajevo: Final Report by the Defense Reform Commission, 2005.

Academic Partnership between PSOTC and Sarajevo University. Sarajevo: Faculty for Political Science, Meeting no. 02-2006, 2006.

Concept of AF BiH Professional Development. Bosnia and Herzegovina, Ministry of Defense, AF BiH Joint Staff, 2010.

Drewienkiewicz, John. A Concept paper on the shaping of Higher Military Education submitted to the working group group established by Decision of the Bosnia and Herzegovina MoD., 2008.

Drewienkiewicz, John. Strawman Paper on Professional Officer Development and Training in the Armed Forces of Bosnia and Herzegovina. Sarajevo : NATO HQ, 2009.

Future Individual Officer Education and Training in the AF BiH - A Concept Paper. DRC Team 2, 2005.

Introductory Document on the Professional Development of Officers and Training in the Armed Forces of Bosnia and Herzegovina. A Document written for the Ministry of Defense of $\mathrm{BiH}, 2009$.

Koncept profesionalnog razvoja časnika OS BiH. Bosnia and Herzegovina, Ministry of Defense, AF BiH Joint Staff, 2011.

Lamballe, Alain. Training of Officers of the Armed Forces in Bosnia and Herzegovina and of Civilians on Defence and Security Issues. Sarajevo: Mission in Bosnia and Herzegovina for Military Academic Institutions, 2002.

Lindsay, Ken. Memorandum on Military Education and Doctrine in the AF BiH. NATO Transition Management Group, 2007.

Report of the U.K. Services Command and Staff College in 2001., 2001

Study into the Feasibility of Establishing a Joint Leadership College for the Armed Forces in Bosnia and Herzegovina . Joint Services Command and Staff College, 2002. 